\title{
An overview on the distribution of Synurella genus in Turkey (Crustacea:Amphipoda)
}

\section{Synurella cinsinin Türkiye'deki dağılımına genel bir bakış (Crustacea: Amphipoda)}

\author{
Murat Özbek \\ Department of Hydrobiology, Faculty of Fisheries, Ege University, Bornova, Izmir, Turkey \\ ozbekm71@gmail.com
}

How to cite this paper:

Özbek, M. (2018). An overview on the distribution of Synurella genus in Turkey (Crustacea:Amphipoda). Ege Journal of Fisheries and Aquatic Sciences, 35(2), 111-114. DOI:10.12714/egejfas.2018.35.2.01

\begin{abstract}
The present knowledge on the distribution of the members of stygophile Synurella Wrześniowski, 1877 genus inhabiting Turkey is very limited. To date, there are only three species, which are Synurella osellai Ruffo, 1974, Synurella lepida Mateus and Mateus, 1990 and Synurella ambulans (O.F. Müller, 1846), have been reported as the representatives of the genus from Turkey. The present study aims to contribute to the knowledge on the distribution of Synurella genus in Turkey. For this purpose, the previous records of Synurella genus from Turkey have been compiled and the new records of S. ambulans and S. osellai were given. Additionally, a map on the distribution of the members of the Synurella genus in Turkey and a key are presented.
\end{abstract}

Keywords: Groundwater, eyeless animal, endemic, stygophile, Anatolia

Öz: Stigofil Synurella Wrześniowski, 1877 cinsinin Türkiye'de dağılım gösteren üyelerinin dağılımları hakkındaki mevcut bilgiler çok az ve kısıtıdır. Bu güne değin, bu cinsin sadece 3 üyesi Synurella osellai Ruffo, 1974, Synurella lepida Mateus and Mateus, 1990 ve Synurella ambulans (O.F. Müller, 1846), Türkiye'den rapor edilmiştir. Bu çalışma, Synurella cinsinin Türkiye'deki dağılımı hakkındaki bilgilere katkı sağlamayı amaçlamaktadır. Bu amaçla, Synurella cinsinin Türkiye'den verilmiş önceki kayıtları derlenmiş ve S. ambulans ile S. osellai için yeni kayıtlar verilmiştir. İlave olarak, cins Synurella cinsinin Türkiye dağılımını gösteren bir harita ve tayin anahtarı sunulmuştur.

Anahtar kelimeler: Yeraltı suyu, gözsüz hayvan, endemik, stigofil, Anadolu

\section{INTRODUCTION}

Synurella Wrześniowski, 1877 is a stygophile amphipod genus occurs in the Holarctic region (Karaman 1974, 1990; Barnard and Barnard 1983). The members of the genus can be found in freshwater habitats in lowlands as well as highland rivers, in small ponds, swamps, temporary pools and small streams. Moreover, some of the species belong to the genus have subterranean populations (Boets et al. 2010). The genus Synurella is stygophile, but lacking typical stygomorphic features such as anophthalmy, depigmentation and reduced fecundity. The females normally produce no less than 11- 20 small-sized eggs (Sidorov and Palatov, 2012).

The genus was represented by three species in Turkey which are Synurella ambulans (O.F. Müller, 1846), Synurella osellai Ruffo, 1974 and Synurella lepida Mateus and Mateus, 1990. S. ambulans is the type species of the genus and has a broad distribution area covering Europe, Russia and Turkey while S. osellai and S. lepida are endemic for Anatolia. The data on the distribution of the members Synurella genus in Turkey are very scarce and comprise only the type localities of the two species indeed, except those on the distribution of $S$. ambulans.

In the present study, the previous records of Synurella genus from Turkey have been compiled and the new records of $S$. ambulans and $S$. osellai were given in addition to distribution map and a key for the genus.

\section{MATERIALS AND METHODS}

Synurella specimens were collected on 11.07.2011 from a ditch near Saklıgöl Lake, Denizli province with a fine-mesh hand-net and preserved in $70 \%$ ethanol in the field (Fig. 1, Fig. 2). Similarly, $S$. osellai specimens were also sampled on 10.10.2014 with a hand net from Solaklı Stream (Trabzon province) and preserved in $4 \%$ formalin solution in field. The sampled specimens were examined and dissected under a 
stereomicroscope, and slide mounts were examined under a compound microscope. Length measurements were made along the dorsal outline of the animals, from the tip of the rostrum to the end of the urosome.
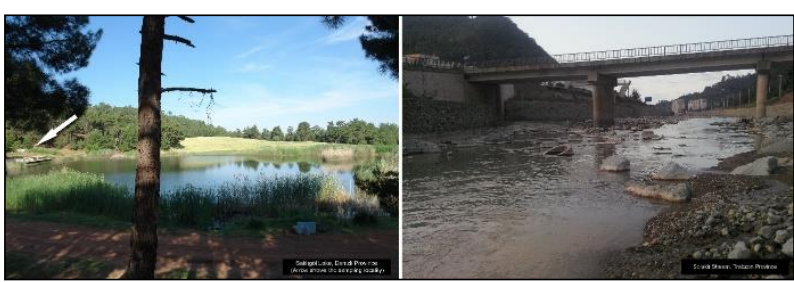

Figure 1. Sampling localities of S. ambulans (left: Saklıgöl Lake; arrow indicates the sampling point) and S. osellai (right: Solaklı Stream)

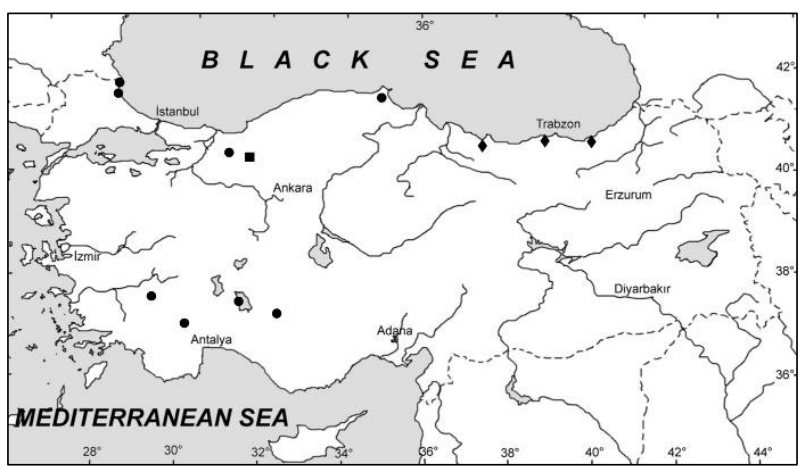

Figure 2. Distribution of Synurella genus in Turkey (S. ambulans: circle; S. lepida: square; S. osellai: diamond).

Some of the physico-chemical parameters were measured in the field with a WTW pH330 model pH-meter, a YSI 30 model SCT-meter (Salinity-Conductivity-Temperature meter), and a WTW Oxi330 model dissolved oxygen-meter.

All material is deposited in the ESFM (Museum of Faculty of Fisheries, Ege University, Izmir, Turkey).

\section{RESULTS AND DISCUSSION}

\section{Synurella ambulans (F. Müller, 1846) (Figs 3-4)}

Material examined: 12 males and 15 females (ESFMMALI/11-04), from a ditch near Saklıgöl Lake (37046'36.64"N29²3'48.99"E), Denizli Province. Sampling date 11.07.2011.

Ecological features of the sampling locality: Water temperature $27.5{ }^{\circ} \mathrm{C}$; $\mathrm{pH} 8.34$; dissolved oxygen $4.3 \mathrm{mg} / \mathrm{l}$; salinity $0.5 \mathrm{ppt}$; electrical conductivity $1038 \mu \mathrm{S}_{25^{\circ} \mathrm{C}}$; altitude 953 m a.s.l.

S. ambulans is the most popular type of this genus in Turkey (Fig. 4). Ruffo (1974), reported this species at four localities from Turkey, which were Sinop, Beyşehir Lake, Abant Lake (Bolu) and Kızılcadağ (Antalya) (Fig. 2). After his study, there was no record of this species from Turkey for a long time. Then, Ustaoğlu et al. (2004) mentioned the existence of $S$. ambulans in Gavur Lake, which is located in the northern part of Taurus Mountains. Özbek et al. (2017) contributed the knowledge on distribution of the species with two records,
Hamam Lake and Erikli Lake, from Turkish Thrace Region. In general, the members of the Synurella genus (except $S$. ambulans) have localized in limited areas. $S$. ambulans has been recorded from a relatively bigger area covering Balkan Peninsula, middle and eastern Europe (Barnard and Barnard, 1983) and western part of Russia. S. ambulans specimens live in semi-subterranean habitats and especially prefers stagnant parts of waters which are connected subterranean waters (Sidorov and Palatov, 2012).

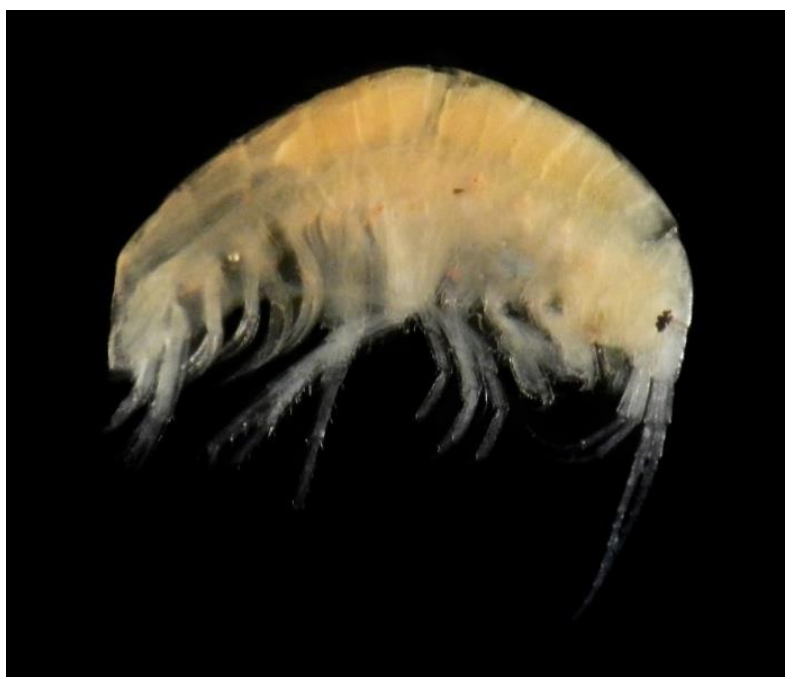

Figure 3. Habitus of Synurella ambulans (†) sampled from Saklıgöl Lake, Denizli Province (Original photo)

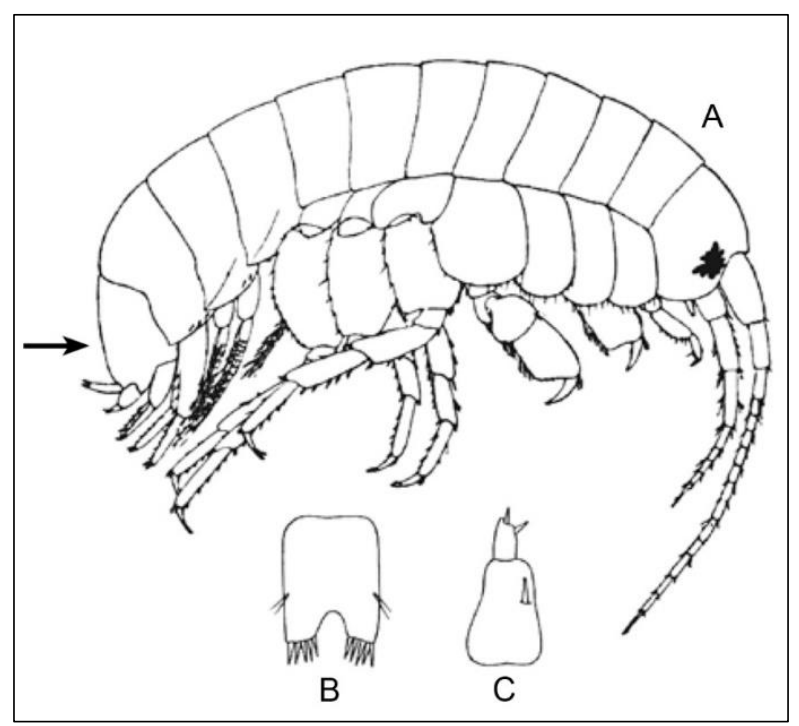

Figure 4. Synurella ambulans (O.F. Müller, 1846). A: habitus; B: telson; C: uropod 3, from Schellenberg (1942)

\section{Synurella osellai Ruffo 1974 (Fig 5)}

Material examined: 2 males and 3 females (ESFMMALI/14-01), from Solaklı Stream, (4052'37.37"N$\left.40^{\circ} 16^{\prime} 53.53 " E\right)$, Trabzon Province. Sampling date 10.10.2014. 
Ecological features of the sampling locality: Water temperature $19.1^{\circ} \mathrm{C}$; $\mathrm{pH} 8.4$; dissolved oxygen $8.9 \mathrm{mg} / \mathrm{l}$;

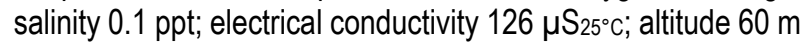
a.s.l.

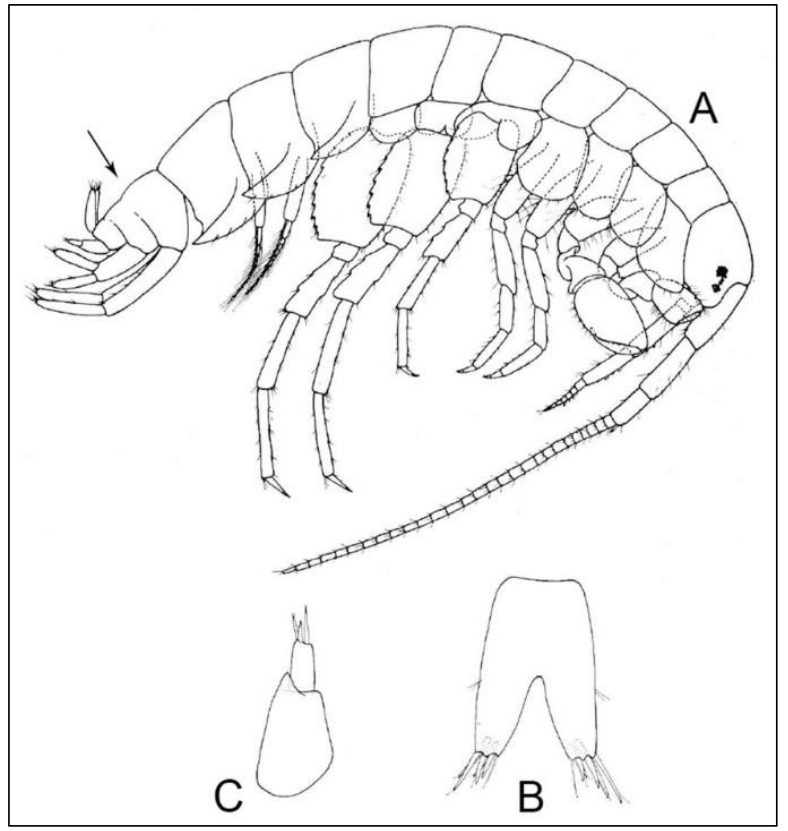

Figure 5. Synurella osellai Ruffo 1974. A: habitus; B: telson; C: uropod 3, from Ruffo (1974)

The species was found at the lower part of the Solaklı Stream just $60 \mathrm{~m}$ above the sea level. The stream was clear and has a pebbly-stony bottom with moderate velocity and weak vegetation at the sampling locality (Fig. 1).

S. lepida, a semi-subterranean amphipod species endemic for Turkey, was described from Adapazarı-Düzce in 1990 for the first time. In its original description (Mateus and Mateus, 1990), morphological features of the species were explained in detail but the drawings of the extremities of both sexes were inadequately presented by the authors (Fig. 6). Along the original drawings and description of $S$. lepida, there are some doubts on the status of the species. The authors stated that there is no sexual dimorphism except the presence of incubating lamellae in females (Mateus and Mateus, 1990); but in Synurella genus there is distinct sexual dimorphism in several species. Similarly, the two other Synurella, S. ambulans and $S$. osellai, species inhabiting Turkish freshwaters show sexual dimorphism especially in the shape of gnathopods and body size (females are bigger than males).

S. osellai has been identified by Ruffo (1974) and the type locality of this endemic species is Tirebolu, a small town placed on NE coast of Turkey (Fig. 2, Fig. 5). After its original description, there was no record for a long time and then the second record of the species was given from Fatsa Town, in Ordu province (Ekinci and Miroğlu, 2017). The present record is the third one for this species.

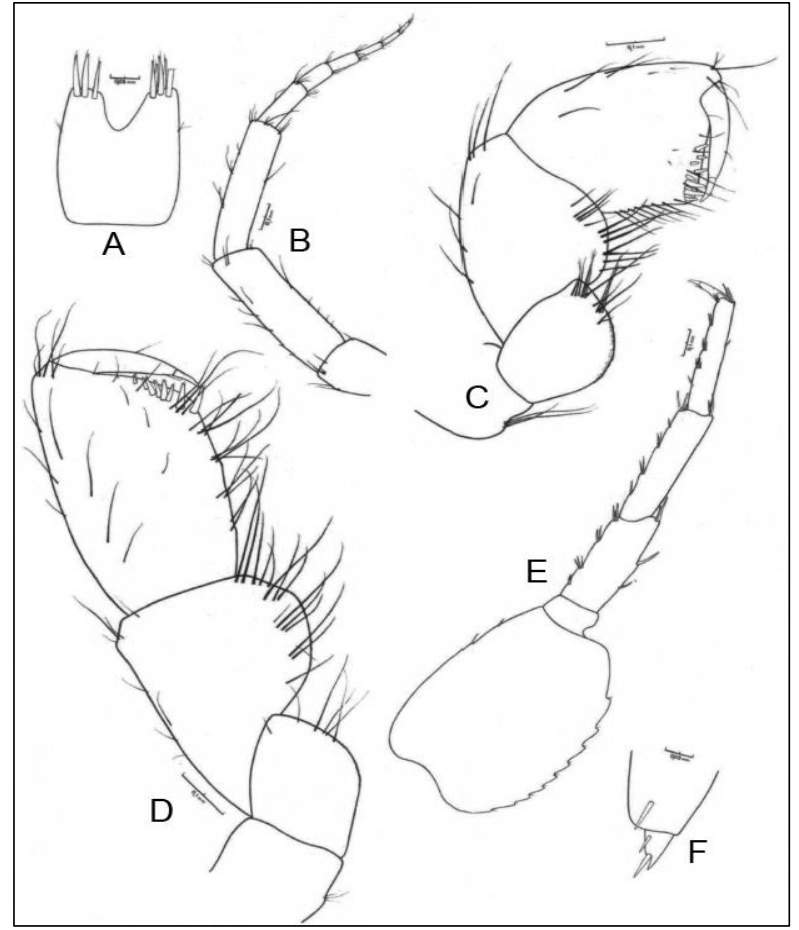

Figure 6. Synurella lepida Mateus and Mateus 1990. A: telson; B: antenna 2; C: gnathopod 1; D: gnathopod 2; E: pereopod 7; F: uropod 3 , from Mateus and Mateus (1990)

In the original description of $S$. lepida, the authors presented a plate including the drawings of the second antenna, first and second gnathopods, pereopod 7 , uropod 3 and telson (Fig. 6). One of the discriminant character given in the plate is the shape and armament of the ganathopods. They look very similar to those of female S. ambulans (Fig. 7). Additionally, the structure and setation of the second antenna is very similar to that of $S$. ambulans. On the other hand, Mateus and Mateus (1990) didn't mention the existence of Csetae on the mandibular palp, but it is a distinct character for $S$. ambulans (Sidorov and Palatov, 2012). Because of poor description and incomplete drawings in its original paper, it is difficult to reach definite conclusion about the status of $S$. lepida. The best solution to solve this puzzle can be to study the type specimens deposited in the Museum of Natural History of Vienna (NHMW Crust.-Coll. Inv.-No. 6435).

Key for the Synurella species inhabiting Turkish inland waters (Adult males only)

1 Mandible palp with C-setae 2

$$
\text { Mandible palp without C-setae ............... S. lepida }
$$

2 Urosome segments coalesced, Antenna 1 short (<20 flagellar segments) S. ambulans

Urosome segments not coalesced, Antenna 1 long (>20 flagellar segments) S. osellai 


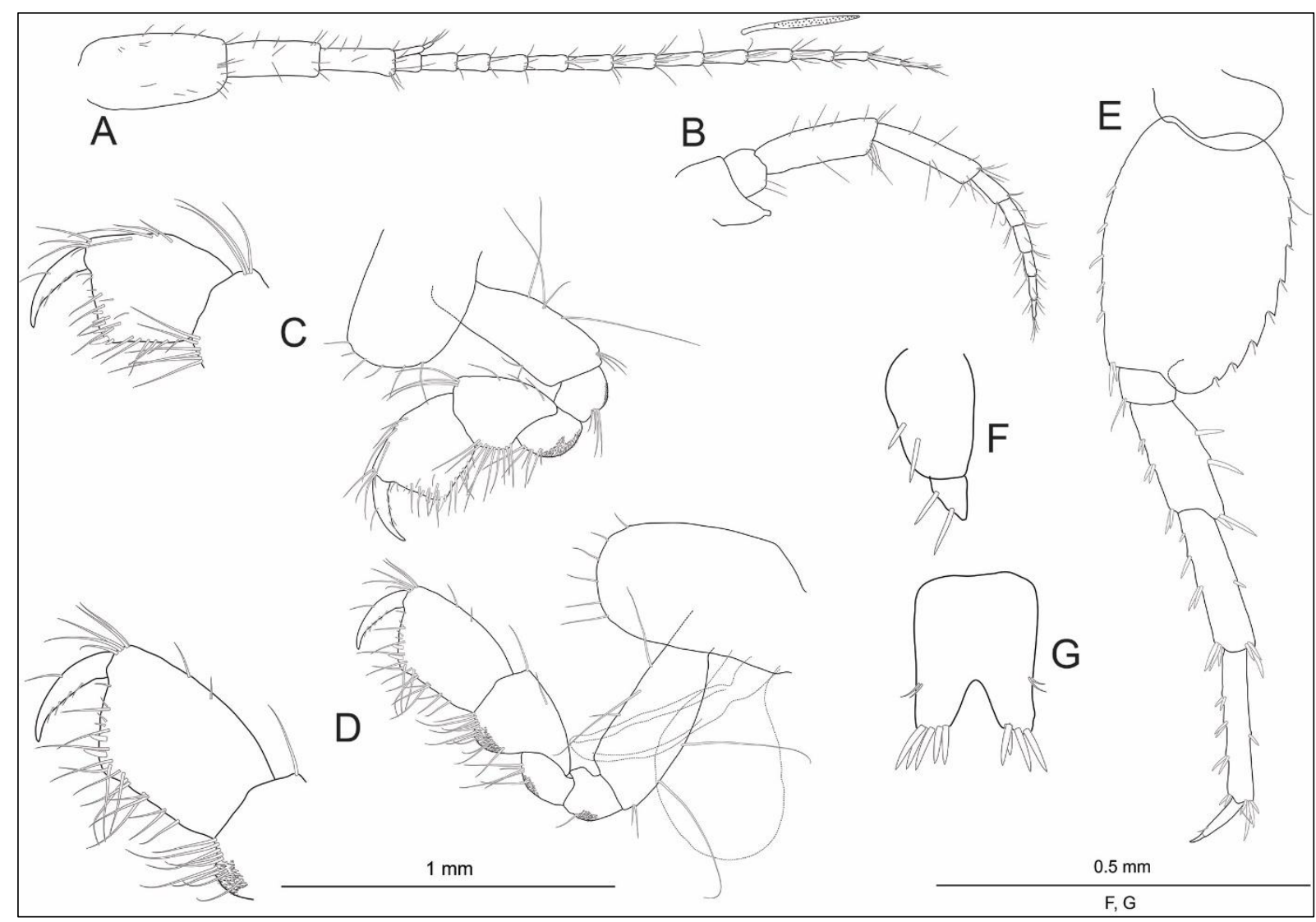

Figure 7. Some extremities of Synurella ambulans (+) sampled from Saklıgöl, Denizli Province. A: antenna 1; B: antenna 2; C: gnathopod 1; D: gnathopod 2; E: pereopod 7; F: uropod 3; G: telson

\section{Acknowledgements}

Some materials of this study ( $S$. ambulans specimens from Saklıgöl Lake) were sampled during a project (2009/SUF/002) supported by the Ege University Research Fund (EURF). I would like to thank the crew of our department for their help in field work and to EURF for their financial support.

\section{REFERENCES}

Barnard J. L. and Barnard, C.M. (1983). Freshwater Amphipoda of the World Virginia: Hayfield Associates.

Boets, P., Lock, K. and Goethals, P.L.M. (2010). First record of Synurella ambulans (Müller, 1846) (Amphipoda: Crangonictidae) in Belgium. Belgian Journal of Zoology 140 (2), 242-243.

Ekinci, M. and Miroğlu, A. (2017). Redescription of Synurella osellai Ruffo, 1974 (Crustacea, Amphipoda) from Ordu Province (Turkey) with Some Taxonomic Notes. Turkish Journal of Fisheries and Aquatic Sciences, 17: DOI: 10.4194/1303-2712-v17_6_31

Karaman, G.S. (1974). 58. Contribution to the Knowledge of the Amphipoda. Genus Synurella Wrzes in Yugoslavia, with remarks on its all world known species, their synonymy, bibliography and distribution (Fam. Gammaridae). Poljoprivreda i Sumarstvo, 20 (2-3), 83-133.

Karaman G.S. (1990). New and interesting species of the genus Synurella Wrzes. 1877 (Fam. Crangonyctidae) from Soviet Union (U.S.S.R.) Glasnik Republickog Zavoda za Zastitu Prirode I Prirodnjackog Muzeja, 23, 25-50.

Mateus, A. and Mateus, E. (1990). Etude d'une collection d'amphipodes, specialement du sud- ouest asiatique, du Museum d'Historie Naturelle de Vienne (Autriche). Annales des naturhistorischer Museum, 91(B), 273- 33.

Özbek, M., Özkan, N. and Çamur-Elipek, B. (2017). Fresh and Brackish-water Amphipod (Crustacea: Amphipoda) Species of Turkish Thrace Region (including Çanakkale Province). Acta Zoologica Bulgarica, 69(4), 493-499.

Ruffo, S. (1974). II genere Synurella Wrzesn. in Anatolia, descrizione di una nuova specie e considerazioni su Lyurella hyrcana Dersh. (Crustacea Amphipoda, Gammaridae). Memorie Del Museo Civico Di Storia Naturale Di Verona, $1(20)$, 389-404.

Schellenberg, A. (1942). 40. Teil. Krebstiere oder Crustacea. IV: Flohkrebse oder Amphipoda. In F. Dahl (Ed.), Die Tierwelt Deutschlands und der angrenzenden Meeresteile nach ihren Merkmalen und nach ihrer Lebensweise, (pp 1-252). Berlin: Jena, Gustav Fischer.

Sidorov, D. and Palatov, D. (2012). Taxonomy of the spring dwelling amphipod Synurella ambulans (Crustacea: Crangonyctidae) in West Russia: with notes on its distribution and ecology. European Journal of Taxonomy, 23, 1-19. DOI: 10.5852/ejt.2012.23

Ustaoğlu, M. R., Balık, S. and Özbek, M. (2004). Contributions to the Knowledge of Malacostraca (Crustacea) Fauna of the Taurus Mountains District (Southern Anatolia). Turkish Journal of Zoology, 28, 91-94. 